\title{
KONSEP PERADILAN SENGKETA PEMILIHAN KEPALA DAERAH
}

\author{
Andi Arfan Sahabuddin \\ Universitas Islam Makassar, andiarshakaputraarsy@gmail.com
}

\begin{abstract}
Abstrak
Dalam Putusan Mahkamah Konstitusi Republik Indonesia Nomor 97/PUU-XI/2013 menyatakan bahwa penanganan sengketa Pemilihan Kepada Daerah tidak lagi menjadi kewenangan Mahkamah Konstitusi. Hal ini membawa konskuensi, di mana sengketa Pemilihan Kepala Daerah akan ditangani melalui Badan Peradilan Khusus. Penelitian ini bertujuan untuk menganalisis konsep peradilan sengketa Pemilihan Kepada Daerah. Penelitian ini menggunakan metode hukum normatif dengan pendekatan peraturan perundang-undangan. Hasil penelitian menunjukkan bahwa pembentukan Badan Peradilan Khusus untuk menangani sengekta Pilkada menjadi suatu keharusan karena hal tersebut merupakan amanat Undang-Undang. Agar penanganan sengketa Pemilihan Kepala Daerah dapat dilakukan dengan efektif, maka Badan Peradilan Khusus tersebut sebaiknya berada di bawah Peradilan Tata Usaha Negara.
\end{abstract}

Kata Kunci : Sengketa Pemilihan Kepala Daerah; Badan Peradilan Khusus

\begin{abstract}
In the Decision of the Constitutional Court of the Republic of Indonesia Number 97/PUU/2013, it is stated that the handling of The Regional Election disputes is no longer be the authority of the Constitutional Court. This raises a consequences, the Regional Election disputes wil be handled through the Special Judiciary. This study aims to analyze the concept of Regional Election disputes court. This study uses a normative method with statute approach. The result of this study shows that the formation of a Special Judiciary to handle the Regional Election disputes is a necessity because it is a mandate of the Law. In order for the handling of Regional Election disputes can be effective, the Special Judiciary should be under the State Administrative Court.
\end{abstract}

Keywords : Regional Election Disputes; Special Judiciary

\section{Pendahuluan}

Perwujudan kedaulatan rakyat yang dilaksanakan dalam sistem demokrasi langsung dalam hal ini Pemilihan Umum (Pemilu) dan Pemilihan Kepala Daerah (Pilkada) harusnya didasarkan pada prinsip dan konsep demokrasi. Melalui sebuah pilihan politik dan hukum, pembuat Undang-undang sepakat untuk memaknai kata "demokratis" pada Pasal 18 ayat (4) Undang-Undang Dasar Negara Republik Indonesia Tahun 1945 sebagai Pemilihan Langsung. ${ }^{1}$ Pada Pasal tersebut juga memberikan peluang agar Gubernur, Bupati dan Walikota dipilih dengan metode demokratis, misalkan melalui Dewan Perwakilan Rakyat Daerah (DPRD). Dalam

\footnotetext{
1 Indonesia, Undang-Undang Dasar Negara Republik Indonesia Tahun 1945, Pasal 18 ayat (4) menyatakan "Gubernur, Bupati dan Walikota masing-masing sebagai kepala pemerintah daerah provinsi, kabupaten, dan kota dipilih secara demokratis."
} 
semangat otonomi daerah, maka Pilkada secara langsung dianggap sebagai cara ampuh untuk menghidupkan demokrasi lokal.

Jimly Asshiddiqie menyatakan frasa "dipilih secara demokratis" dalam Pasal 18 ayat (4) UUD NRI Tahun 1945 bersifat luwes, sehingga dapat diartikan sebagai pemilihan secara langsung. ${ }^{2}$ Pasal inilah yang dijadikan dasar untuk menyelenggarakan pemilihan langsung kepala daerah mulai dari tingkat Provinsi yang dipimpin Gubernur dan di tingkat Kabupaten/Kota yang dipimpin oleh Bupati atau Walikota. Secara original intent, keberadaan Pasal 18 ayat (4) UUD NRI Tahun 1945 mengenai pemilihan kepala daerah secara demokratis disahkan pada proses amandemen tahun 2000. Lain halnya dengan Pasal 22E tentang Pemilihan Umum yang disahkan pada tahun 2001. Pasal 22E menyatakan dengan tegas bahwa Presiden dan Wakil Presiden, DPR, DPD dan DPRD dipilih secara langsung. Usulan mengenai adanya pemilihan kepala daerah langsung sudah pernah diungkapkan oleh Fraksi PPP yang menyatakan Gubernur, Bupati dan Walikota dipilih secara langsung oleh Rakyat yang selanjutnya diatur oleh UU. ${ }^{3}$ Namun terdapat kesepakatan bahwasanya norma yang telah disepakati pada amandemen sebelumnya tidak dapat diubah pada masa perubahan selanjutnya. ${ }^{4}$ Oleh karenanya, redaksi Pasal 18 ayat (4) UUD NRI Tahun 1945 dianggap telah final.

Pemilihan kepala daerah adalah cara konstitutional untuk pengisian kepala pemerintahan daerah tingkat provinsi, kabupaten dan kota untuk dipimpin oleh seorang Gubernur, Bupati dan Walikota. Dalam konteks otonomi daerah, pemerintah daerah bersama dengan DPRD berhak untuk menjalankan pemerintahan otonomi seluas-luasnya seperti dengan menetapkan peraturan daerah. Sehingga penting bagi masyarakat juga turut terlibat dalam penentuan pemimpin daerahnya melalui mekanisme pilkada langsung. Proses Pilkada dapat menjadi salah satu sarana integrasi bangsa untuk membiarkan masyarakat memilih sendiri kualitas pemimpin yang diinginkan. Ia adalah sistem untuk mengejewantahkan pemimpin idaman yang berasal dari masyarakat itu sendiri. ${ }^{5}$ Selain itu Pilkada juga dinilai dapat mengakomodir sistem seleksi terpadu untuk melahirkan calon kepala daerah yang berkualitas. ${ }^{6}$ Mengingat makna penting Pilkada itulah maka timbul urgensi untuk menjaga kualitas proses dari

\footnotetext{
2 Jimly Asshiddiqie, (2002), Konsolidasi Naskah UUD 1945 Setelah Perubahan Keempat, Pusat Studi Hukum Tata Negara Fakultas Hukum Universitas Indonesia, Depok, , hal. 22.

${ }^{3}$ Majelis Permusyawaratan Rakyat, 2000, Buku Kedua Jilid 3 C, Risalah Rapat Panitia Ad Hoc I Sidang Tahunan 2000, Sekretariat Jenderal Majelis Permusyawaratan Rakyat, Jakarta, hal. 255-273.

${ }^{4}$ Mahkamah Konstitusi Republik Indonesia, 2010, Naskah Komprehensif Perubahan Undang- Undang Dasar Negara Republik Indonesia Tahun 1945, Buku IV: Kekuasaan Pemerintahan Negara Jilid 2, Edisi Revisi, Sekretariat Jenderal dan Kepaniteraan Mahkamah Konstitusi, Jakarta, hal. 1421.

5 Kariaman Sinaga, 2016, Efektitas Regulasi dan Perannya dalam Penyelenggaraan Pemilukada: Dialektika Hukum dan Etika Pemilukada Serentak, Dewan Kehormatan Penyelenggara Pemilu RI, Jakarta,, hal. 142-143.

${ }^{6}$ Joko J. Prihatmoko, 2008, Mendemokrasikan Pemilu, Pustaka Pelajar, Yogyakarta, hal. 195-196.
} 
penyelenggaraan Pilkada. Dengan kata lain, terselenggaranya Pilkada yang baik menjadi penentu kualitas pemerintahan dan keberhasilan demokrasi. ${ }^{7}$

Pemilu dilakukan melalui beberapa tahapan utama dan dalam tahapan penyelenggaraan Pemilu terdapat kemungkinan terjadi pelanggaran atau sengketa. Perbedaan penghitungan perolehan suara antara Komisi Pemilihan Umum dan peserta pilkada kerap terjadi dan berpotensi mencederai demokrasi. Kecurangan (fraud), kekhilafan (mistake) maupun strategi pemenangan Pemilu yang tidak melanggar hukum tetapi menurunkan kepercayaan publik (non-fraudulent misconduct) merupakan beberapa hal yang kemungkinan menjadi penyebab. Sayangnya hingga kini masih belum jelas mengenai pengadilan mana yang dianggap cocok untuk mengadili perselisihan hasil Pilkada pasca Mahkamah Konstitusi memutus sengketa Pilkada bukan termasuk pemilihan umum.

Melalui Putusan Nomor 97/PUU-XI/2013, Mahkamah Konstitusi menyatakan tidak lagi berwenang untuk mengadili sengketa hasil pilkada karena secara limitatif Pasal 24C UUD NRI Tahun 1945 hanya memberikan kewenangan untuk mengadili perkara pemilu saja dan tidak termasuk Pilkada. Namun dalam putusan itu Mahkamah Konstitusi juga menyatakan bahwa selama belum terbentuk pengadilan khusus Pilkada maka Mahkamah Konstistusi akan tetap mengadili perselisihan hasil Pilkada. Sembari menunggu pembentuk undang-undang menentukan kemana perselisihan hasil Pilkada berlabuh, Pasal 157 ayat (3) Undang-Undang Nomor 10 tahun 2016 tentang Pilkada menyatakan bahwa perkara perselisihan penetapan perolehan suara tahap akhir hasil Pilkada diperiksa dan diadili oleh Mahkamah Konstitusi sampai dibentuknya badan peradilan khusus. Dalam masa transisi, sengketa hasil pemilihan kepala daerah masih ditangani oleh Mahkamah Konstitusi pada tahun 2016, tahun 2017 dan Tahun 2018.

Wacana Pemilihan Kepala Daerah merupakan sesuatu yang sangat menarik dibahas dewasa ini, karena wacana Pilkada serentak yang akan dilaksanakan di Tahun 2024 di 415 Kabupaten dan 93 Kota. Penyelenggaraan pilkada akbar tersebut tentu memiliki konsekuensi logis yakni munculnya sengketa pilkada dengan jumlah yang tidak sedikit. Pengalaman Pilkada serentak sebelumnya telah membuktikan bahwa sengketa Pilkada tidak pernah surut. Hal tersebut dapat dilihat dari rekapitulasi perkara PHPU kepala daerah dan wakil kepala daerah. Mahkamah Konstitusi mencatat bahwa pada 2015 terdapat 269 daerah yang menggelar Pilkada Serentak. Jumlah permohonan sengketa yang masuk ke Mahkamah Konstitusi ketika itu sebanyak 152 perkara, dan pada 2017 dari 101 daerah yang menggelar Pilkada Serentak, 60 diantaranya mengajukan sengketa ke Mahkamah Konstitusi,

\footnotetext{
7 Djoko Suyanto, 2012, Evaluasi Pemilukada dari Prespektif Ketahanan Nasional: Demokrasi Lokal, Evaluasi Pemilukada di Indonesia" Konpress, Jakarta, hal. 25.
} 
pada tahun 2018 dari 171 daerah yang menggelar Pilkada, 72 mengajukan sengketa ke Mahkamah Konstitusi. ${ }^{8}$

Dari hal tersebut terlihat bahwa lebih dari 50\% penyelenggaraan Pilkada mengajukan sengketa ke Mahkamah Konstitusi. Sehingga, tidak dapat terbayangkan berapa banyak sengketa Pilkada yang akan mencul pada Pilkada serentak di 415 kabupaten dan 93 kota pada 2024. Terlebih lagi, Pilkada serentak tersebut akan dilaksanakan secaraan bersamaan pula dengan pemilu legislatif dan pemilu presiden. Berdasarkan uraian seperti yang terpapar di atas, maka penelitian ini berangkat dari pertanyaan dasar yang sekaligus merupakan permasalahan pokok studi, yaitu bagaimanakah gagasan metode Pengadilan Khusus Pemilihan Kepala Daerah?

\section{Metode}

Berdasarkan isu yang akan dianalisis, penelitian dalam penulisan ini merupakan penelitian hukum yang akan mengkaji dan menganalisis konsep pengadilan khusus sengketa Pilkada. Metode penelitian Hukum ini adalah Metode Penelitian Hukum Normatif yaitu suatu metode penelitian yang orientasinya ditujukan pada aspek Hukum. Untuk menentukan jawaban atas berbagai pertanyaan yang terkandung pada permasalah dalam penelitian ini digunakan pendekatan Perundang-undangan (Statute approach) dengan tidak melupakan pengungkapan ratio legis dan dasar ontologis lahirnya perundang-undangan khususnya kewenangan Mahkamah Konstitusi dalam menyelesaikan sengketa Pilkada. Selain itu, digunakan pula pendekatan konseptual (conseptual approach) dengan beranjak dari pandangan-pandangan dan doktrin-doktrin yang berkembang dalam ilmu Hukum. Selain itu, digunakan pula pendekatan perbandingan, khususnya praktek Peradilan Khusus Pemilihan Umum Kepala Daerah di beberapa negara lain.

Data yang digunakan dalam penulisan ini adalah data sekunder yang terdiri dari bahan hukum primer dan bahan hukum sekunder. Bahan hukum primer berupa peraturan perundang-undangan asas-asas dan hasil-hasil penelitian terkait dengan kewenangan Mahkamah Konstitusi dalam penyelesaian sengketa Pemilihan Kepala Daerah. Bahan hukum sekunder berupa dokumen-dokumen dan literatur/bacaan yang mencakup dasar-dasar teoretik atau doktrin yang relevan dengan penyelesaian sengketa Pemilihan Kepala Daerah termasuk bahan hukum yang diperoleh dari internet, hasil seminar, simposium dan hasil lokakarya yang terkait dengan obyek penelitian. Data dan bahan-bahan kajian yang diperoleh, dikumpulkan dan diklasifikasikan berdasarkan urgensi dan relevansinya kemudian dianalisis secara logis-deduktif (deduksi logis).

\footnotetext{
${ }^{8}$ www.mahkamahkonstitusi.go.id
} 


\section{Konsepsi Kompetensi dan Kewenangan}

\subsection{Tinjauan mengenai Kompetensi}

Dalam Kamus Besar Bahasa Indonesia, kompetensi adalah kewenangan (kekuasaan) untuk menentukan (memutuskan sesuatu). Sedangkan menurut Kamus Hukum, Kompetensi merupakan cakupan dan batasan dari wewenang Pengadilan untuk memutus suatu perkara. Pengertian kompetensi yang mendekati dalam aspek hukum adalah kewenangan untuk mengadili perkara atau sengketa dari suatu pengadilan. ${ }^{9}$ Menurut Roihan Rasyid, kompetensi seringkali juga dimaknai kewenangan, kadang juga dimaknai dengan kekuasaan. Adapun kompentensi yang dimaksud disini adalah kewenangan mengadili yang dimiliki oleh lembaga peradilan. Roihan Rasyid membagi kompetensi menjadi dua, yaitu Kompetensi Relatif dan Kompetensi Absolut.

Kompetensi Relatif diartikan sebagai kekuasaan pengadilan yang satu jenis dan satu tingkatan, dalam perbedaannya dengan kekuasaan pengadilan yang sama jenis dan sama tingkatan lainnya. Dengan kata lain bahwa setiap lembaga peradilan mempunyai wilayah hukum tertentu, dalam hal ini meliputi satu kota atau satu kabupaten. Kompetensi Absolut artinya kekuasaan pengadilan yang berhubungan dengan jenis perkara atau jenis pengadilan, atau tingkatan pengadilan, dalam perbedaanya dengan jenis perkara atau jenis pengadilan, atau tingkatan pengadilannya. Misalnya, pengadilan Agama berkompeten atas perkara perkawinan bagi mereka yang beragama Islam, sedangkan bagi yang selain Islam menjadi kompetensi Peradilan Umum. Kompetensi dari suatu pengadilan untuk memeriksa, mengadili, dan memutus suatu perkara berkaitan dengan jenis dan tingkatan pengadilan yang ada berdasarkan peraturan perundang-undangan yang berlaku.

R. Soeroso membagi kewenangan mengadili dalam kekuasaan kehakiman atribusi, dan kekuasaan kehakiman distribusi. Atribusi kekuasaan kehakiman adalah kewenangan mutlak, atau juga disebut kompetensi absolut, yaitu kewenangan badan pengadilan dalam memeriksa jenis perkara tertentu dan secara mutlak tidak dapat diperiksa oleh badan pengadilan lain. Sedangkan tentang distribusi kekuasaan Pengadilan atau apa yang dinamakan kompetensi relative, atau kewenangan nisbi ialah bahwa Pengadilan Negeri ditempat tergugat tinggal (berdomisili) yang berwenang memeriksa gugatan atau tuntutan hak. ${ }^{10}$

Menurut Subekti, kompetensi juga dimaknai sebagai kekuasaan atau kewenangan. Subekti sendiri membagi kompetensi atau kewenangan menjadi dua, yakni kompetensi absolute (kewenangan absolute) dan kompetensi relative (kewenangan relative). Komptensi absolute terkait dengan kekuasaan atau wewenang berbagai jenis pengadilan dalam suatu Negara yang diatur dalam

\footnotetext{
${ }^{9}$ Abdul Kadir Muhammad, (2000), Hukum Perdata Indonesia, Citra Aditya Bakti, Bandung, hal. 26

${ }^{10}$ R. Soeroso, (2001), Praktek Hukum Acara Perdata; Tata Cara dan Proses Persidangan, Sinar Grafika, Jakarta, hal. 77
} 
undang-undang Pokok Kekuasaan Kehakiman. Sedangkan kekuasaan relative berkaitan dengan pembagian kekuasaan antara badan-badan pengadilan dari tiaptiap jenis pengadilan tersebut, yang umumnya diatur dalam undang-undang tentang hukum acara. Untuk membedakan kompetensi absolute dan relative subuah lembaga peradilan dapat dilihat dari undang-undang yang mengaturnya. Kompetensi absolute dapat ditinjau dalam undang-undang Pokok Kehakiman, sedangkan kompetensi relative dapat ditinjau dari undang- undang hukum acara lembaga peradilan tersebut.

\subsection{Tinjauan mengenai Kewenangan}

Pasal 1 ayat (6) Undang-Undang Nomor 30 Tahun 2014 tentang Adminstrasi Pemerintahan, yang dimaksud dengan kewenangan adalah kekuasaan Badan dan/atau Pejabat Pemerintahan atau penyelenggara negara lainnya untuk bertindak dalam ranah hukum publik. Adanya kewenangan yang dimiliki oleh sebuah lembaga Negara menjadi sangat penting guna menjalankan roda pemerintahan. Menurut Philipus M. Hadjon bahwa kewenangan hanya dapat diperoleh dengan dua cara, yaitu atribusi atau dengan delegasi. ${ }^{11}$

Pandangan lain mengenai kewenangan diutarakan oleh Abdul Rasyid Thalib yang menyatakan bahwa kewenangan yang dimiliki oleh organ (institusi) pemerintahan atau Lembaga negara dalam melakukan perbuatan nyata (riil), mengadakan pengaturan, atau mengeluarkan keputusan selalu dilandasi kewenangan yang diperoleh dari konstitusi secara atribusi, ataupun delegasi, ataupun mandat. ${ }^{12}$ Pengertian Atribusi menunjuk pada kewenangan yang asli atas dasar konstitusi atau ketentuan Hukum Tata Negara. Pada kewenangan yang diperoleh dengan cara delegasi merupakan suatu pelimpahan wewenang kepada organ pemerintahan yang lain. Adapun pada mandat tidak terjadi pelimpahan apapun dalam arti pemberian wewenang. Akan tetapi pejabat yang diberi mandat bertindak atas nama pemberi mandat. ${ }^{13}$

Berkaitan dengan atribusi, delegasi, dan mandat, H.D Van Wijk dan Wililem Konijnenbelt mendefinisikan Atribusi adalah pemberian wewenang pemerintahan oleh pembuat undang-undang kepada organ pemerintahan. Delegasi adalah pelimpahan wewenang pemerintahan dari satu organ pemerintahan kepada organ pemerintahan yang lainnya. Mandat adalah pemberian izin yang dilakukan oleh organ pemerintahan agar kewenangannya dijalankan oleh organ pemerintahan yang lain atas namanya. ${ }^{14}$

\footnotetext{
${ }^{11}$ Philipus M. Hadjon, et. al, (2008), Pengantar Hukum Adminstrasi Negara, UGM Pers, Jogjakarta, hal. 130

12 Abdul Rasyid Thalib, (2006), Wewenang Mahkamah Konstitusi dan Implikasinya dalam sisitem Ketatanegaraan Republik Indonesia, Citra Aditya Bakti, Bandung, hal. 217

13 Ibid

${ }^{14}$ Ridwan H.R, (2006), Hukum Administrasi Negara, Raja Grafindo Persada, Jakarta, hal. 105.
} 
Kewenangan membuat keputusan oleh lembaga Negara hanya dapat diperoleh oleh dengan dua cara, yaitu atribusi atau dengan delegasi.23 Dalam Pasal 1 ayat (22) Undang-Undang Nomor 30 tahun 2014 tentang Administrasi Pemerintahan disebutkan bahwa Atribusi adalah pemberian Kewenangan kepada Badan dan/atau Pejabat Pemerintahan oleh Undang-Undang Dasar Negara Republik Indonesia Tahun 1945 atau Undang-Undang. Sedangkan pengertian delegasi berdasarkan Pasal 1 ayat (23) Undang-Undang Nomor 30 tahun 2014 tentang Administrasi Pemerintahan adalah adalah pelimpahan Kewenangan dari Badan dan/atau Pejabat Pemerintahan yang lebih tinggi kepada Badan dan/atau Pejabat Pemerintahan yang lebih rendah dengan tanggung jawab dan tanggung gugat beralih sepenuhnya kepada penerima delegasi".

Pasal 1 ayat 24 Undang-Undang Nomor 30 tahun 2014 tentang Administrasi Pemerintahan juga ditambakan tentang kewenangan yang diperoleh Badan atau Pejabat Pemerintahan, yakni dengan cara pemberian Mandat, yakni pelimpahan kewenangan dari Badan dan/atau Pejabat Pemerintahan yang lebih tinggi kepada Badan dan/atau Pejabat Pemerintahan yang lebih rendah dengan tanggung jawab dan tanggung gugat tetap berada pada pemberi mandat.

\section{Perselisihan Hasil Pemilihan Gubernur, Bupati, dan Walikota}

Pada 2008, kewenangan Mahkamah Konstitusi untuk menyelesaikan perselisihan hasil pemilihan umum yang semula hanya meliputi pemilihan umum Presiden dan Wakil Presiden serta pemilihan umum legislatif, kemudian diperluas meliputi juga pemilihan umum kepala daerah. ${ }^{15}$ Setelah mengalami berbagai perubahan dasar hukum Mahkamah Konstitusi saat ini memiliki kewenangan (sementara) untuk menyelesaikan sengketa/perkara perselisihan hasil pemilihan gubernur, bupati, dan walikota.

Kewenangan demikian bermula dari Pasal 106 ayat (1) dan ayat (2) UndangUndang Nomor 32 tahun 2004 tentang Pemerintahan Daerah yang mengatur bahwa keberatan berkenaan dengan hasil penghitungan suara yang mempengaruhi terpilihnya Pasangan Calon diajukan ke Mahkamah Agung. Kemudian Pasal 236 C Undang-Undang Nomor 12 tahun 2008 tentang Perubahan Kedua Atas Undang-Undang Nomor 32 Tahun 2004 mengatur bahwa, penanganan sengketa hasil penghitungan suara pemilihan kepala daerah oleh Mahkamah Agung dialihkan kepada Mahkamah Konstitusi paling lama 18 (delapan belas) bulan sejak Undang-Undang ini diundangkan. Pengalihan demikian secara nyata mulai dilaksanakan dengan ditandatanganinya Berita Acara Pengalihan Wewenang Mengadili oleh Ketua Mahkamah Agung dan Ketua Mahkamah Konstitusi pada 29 Oktober 2008. 
Undang-Undang Nomor 22 tahun 2007 tentang Penyelenggara Pemilihan Umum sebagaimana telah diubah dengan Undang-Undang Nomor 15 tahun 2011 tentang Penyelenggara Pemilihan Umum memasukkan pemilihan kepala daerah sebagai bagian dari rezim pemilihan umum. Selanjutnya dalam Putusan MK Nomor 97/PUU-XI/2013, bertanggal 19 Mei 2014, dengan pertimbangan bahwa Pilkada tidak diatur berdasarkan Pasal 22E UUD NRI Tahun 1945, melainkan diatur berdasarkan Pasal 18 ayat (4) UUD NRI Tahun 1945. Mahkamah Konstitusi menyatakan bahwa pemilihan kepala daerah bukan merupakan rezim Pemilu sehingga penyelesaian perselisihan hasil pemilihan umum kepala daerah bukan kewenangan Mahkamah Konstitusi.

Setelah putusan MK demikian, kemudian muncul Undang-Undang Nomor 1 tahun 2015 tentang Penetapan Peraturan Pemerintah Pengganti Undang-Undang Nomor 1 Tahun 2014 tentang Pemilihan Gubernur, Bupati, dan Walikota Menjadi Undang-Undang sebagaimana telah diubah dengan Undang-Undang Nomor 8 tahun 2015 tentang Perubahan Atas Undang-Undang Nomor 1 Tahun 2015 tentang Penetapan Peraturan Pemerintah Pengganti Undang-Undang Nomor 1 Tahun 2014 tentang Pemilihan Gubernur, Bupati, dan Walikota Menjadi Undang-Undang mengatur pemilihan kepala daerah dilaksanakan serentak dan menegaskannya sebagai bukan bagian rezim Pemilu, melainkan disebut dengan istilah "Pemilihan Gubernur, Bupati, dan Walikota".

Dikeluarkannya pemilihan kepala daerah dari rezim pemilu mengakibatkan Mahkamah Konstitusi dalam mengadili perkara perselisihan hasil pemilihan kepala daerah tidak lagi berangkat dari posisi sebagai the guardian of the constitusion. Hal demikian mengakibatkan Mahkamah Konstitusi tidak lagi dapat membuat terobosan berupa mengoreksi ketentuan undang-undang yang menghambat atau menghalangi keadilan berdasarkan UUD NRI Tahun 1945. Setelah bukan lagi rezim pemilu, maka putusan perkara perselisihan pemilihan kepala daerah oleh MK hanya semata-mata mengenai perselisihan hasil penghitungan suara.

Pasal 157 ayat (3) dan ayat (4) Undang-Undang Pemilihan Gubernur, Bupati, dan Walikota memberikan kembali kewenangan menyelesaikan perselisihan hasil pemilihan kepala daerah kepada Mahkamah Konstitusi. Pasal 157 ayat (3) a quo menyatakan, "perkara perselisihan penetapan perolehan suara hasil Pemilihan diperiksa dan diadili oleh Mahkamah Konstitusi sampai dibentuknya badan peradilan khusus". Adapun Pasal 157 ayat (4) menyatakan, "Peserta Pemilihan dapat mengajukan permohonan pembatalan penetapan hasil penghitungan perolehan suara oleh KPU Provinsi dan KPU Kabupaten/Kota kepada Mahkamah Konstitusi".

Perintah Pasal 157 ayat (3) Undang-Undang a quo bermakna bahwa ketika telah dibentuk/berdiri badan peradilan khusus yang menangani perkara perselisihan hasil pemilihan kepala daerah, maka saat itu juga Mahkamah Konstitusi 
tidak lagi berwenang mengadili perkara jenis dimaksud. Badan peradilan khusus tersebut menurut Pasal 157 ayat (2) juncto Pasal 201 ayat (7) Undang-Undang a quo dibentuk sebelum pelaksanaan Pemilu serentak nasional pada tahun 2024.

\section{Peradilan Sengketa Pemilihan Kepala Daerah}

Pembentukan Badan Peradilan Khusus merupakan isu yang cukup hangat dari berbagai kalangan sejak munculnya wacana penyelenggaraan Pilkada secara serentak pada tahun 2024 di 415 Kabupaten dan 93 Kota. Mengingat jumlah daerah yang akan melaksanakan Pilkada secara serentak, maka tentu saja dapat menimbulkan konsekuensi logis dimana akan timbul sengketa Pilkada dengan jumlah yang juga tidak sedikit. Keberadaan Badan Peradilan Khusus yang menangani sengketa Pilkada bukanlah merupakan hal yang baru dalam sistem ketatanegaraan di berbagai negara. Sebagaimana diketahui, negara-negara seperti Uruguay, Brazil, Jerman, Costa Rica, Nigeria, Meksiko dan Inggris merupakan negara yang yang memiliki Badan Peradilan Khusus Pilkada dan mampu menangani sengketa Pilkada secara efektif. ${ }^{16}$ Di Brazil misalnya, sistem penanganan sengketa Pemilu di negara ini termasuk yang paling efektif di dunia. Dalam hal ini, terdapat badan peradilan khusus, yaotu Superior Electoral Court (SEC) yang terdiri dari tujuh hakim yang diangkat melalui pemilihan secara rahasia dan penunjukan oleh Presiden. SEC memiliki wewenang yang sangat luas yang mencakup keseluruhan aspek Pemilu dan Partai Politik. Kewenangan SEC meliputi pengesahan pendaftaran partai politik serta calon Presiden dan Wakil Presiden, menangani konflik yurisdiksi antara pengadilan pemilu daerah, menangani perselisihan hasil akhir pemilu, menerima pengajuan banding dari pengadilan pemilihan daerah, mengesahkan pembagian negara menjadi daerah-daerah pemilihan, menjawab pertanyaan dari partai politik yang berkaitan dengan masalahmasalah pemilu, mengesahkan perhitungan suara, serta mengambil tindakantindakan lainnya yang dianggap perlu untuk melaksanakan undang-undang pemilu. ${ }^{17}$

Di Meksiko, untuk menangani sengketa Pemilihan Umum dibentuk Pengadilan Pemilu pada Pengadilan Federal (Electoral Court of The Federal Judiciary, Tribunal Electoral del Poder Judicial de la Federacion, -TEPJF-), yang memiliki tanggung jawab untuk mengakkan undang-undang Pemilu bersama dengan badan penyelenggara Pemilu Federal atau Fedeal Electoral Institute (IFE). Kewenangan yang dimiliki oleh IFE adalah menegakkan peraturan Pemilu yang bersifat administratif, sedangkan TEPJF diberikan mandat untuk menyelesaikan

\footnotetext{
${ }^{16}$ Siti Nurhalimah, (2017), Pembentukan Badan Peradilan Khusus Pilkada, Buletin Hukum dan Keadilan 'Adalah, v1n5c, hal. 26

17 Bisariyadi, Anna Triningsih, Meyrinda Rahmawaty H, Alia Harumdani W, (2012), Komparasi Mekanisme Penyelesaian Sengketa Pemilu di Beberapa Negara Penganut Paham Demokrasi Konstitusional, Jurnal Konstitusi, v9n3, hal. 551
} 
sengketa Pemilu dan mengesahkan keabsahan hasil Pemilu. ${ }^{18}$ Hal ini berarti, keberadaan Badan Peradilan Khusus di Indonesia merupakan suatu bentuk pembaharuan hukum yang relevan dengan realitas hukum yang akan terjadi di masa akan datang.

Dalam revisi Undang-Undang Nomor 1 Tahun 2010 memang mengamanatkan Mahkamah Konstitusi menangani sengketa Pilkada sepanjang belum dibentuk badan peradilan khusus. Dalam revisi Undang-Undang tersebut dikatakan bahwa Badan Peradilan Khusus dibentuk paling lama sebelum pelaksanaan Pilkada serentak secara nasional. Salah satu lembaga yang diamanatkan atau diberi tempat secara khusus oleh Undang-Undang untuk mengadili sengketa Pemilihan Kepala Daerah adalah "Badan Peradilan Khusus". Memang Badan ini tidak secara langsung disebut secara yuridis (berdasarkan Undang-Undang Nomor 48 Tahun 2009) akan menangani sengketa Pilkada langsung, akan tetapi dapat dibentuk untuk menjadi solusi yuridis atas problem yuridis tertentu di tengah masyarakat, diantaranya Pilkada langsung.

Pasal 1 angka 8 Undang-Undang Nomor 48 Tahun 2009 menentukan bahwa "Pengadilan Khusus adalah pengadilan yang mempunyai kewenangan untuk memeriksa, mengadili dan memutus perkara tertentu yang hanya dapat dibentuk dalam salah satu lingkungan badan peradilan yang berada di bawah Mahkamah Agung yang diatur dalam undang-undang". Lebih lanjut Pasal 27 ayat (1) UndangUndang Nomor 48 Tahun 2009 menentukan bahwa "Pengadilan khusus hanya dapat dibentuk dalam salah satu lingkungan peradilan yang berada di bawah Mahkamah Agung sebagaimana dimaksud dalam Pasal 25". Jika Badan Perdilan Khusus ini dapat terbentuk, yang tentu saja diantaranya dengan belajar pada paradigma dan sistem penyelesaian perselisihan pilkada langsung yang pernah ditangani MK, maka hal ini dapat menjadi solusi terbaik untuk "mengurangi" beban Mahkamah Konstitusi, yang idealnya terfokus pada penanganan problem konstitusional yang menjadi kewenangan dan kewajiban Mahkamah Konstitusi itu sendiri.

Undang-Undang Nomor 48 Tahun 2009 memberikan kewenangan kepada pembentuk undang-undang untuk membentuk badan peradilan khusus, termasuk badan peradilan khusus yang mempunyai kewenangan untuk menyelesaikan sengketa hasil Pilkada langsung. Badan peradilan khusus penyelesaian sengketa Pilkada tersebut harus dibentuk di bawah 4 (empat) badan peradilan yang ada. Oleh karena itu, badan peradilan khusus yang ditentukan dalam Pasal 157 ayat (1) Undang-Undang Nomor 8 Tahun 2015 sebaiknya dibentuk di bawah Peradilan Tata Usaha Negara (PTUN), mengingat sengketa hasil Pilkada langsung merupakan sengketa administratif yang menilai keabsahan keputusan penyelenggara Pilkada langsung terkait hasil Pilkada langsung. Badan Peradilan Khusus Pilkada sebaiknya

\footnotetext{
${ }^{18}$ Ibid, hal. 552
} 
berada di bawah Peradilan Tata Usaha Negara karena bersentuhan langsung dengan permasalahan administrasi penyelenggaraan Pilkada yang mana hal tersebut terkait dengan Keputusan Tata Usaha Negara. Badan Peradilan Khusus ini bisa juga dalam lingkup Pengadilan Tinggi Tata Usaha Negara karena melihat letak PTUN yang berada di setiap Provinsi. Dari pertimbangan geografis tersebut, sengketa Pilkada yang ditangani oleh Badan Peradilan Khusus dapat dilakukan secara efektif.

\section{Penutup}

Keberadaan Badan Peradilan Khusus yang memiliki kewenangan untuk menangani sengketa Pilkada merupakan sebuah keniscayaan, mengingat hal tersebut merupakan amanat yang tertuang dalam Undang-Undang. Selain itu, potensi timbulnya sengketa pada Pilkada serentak secara nasional sangat besar, sehingga dibutuhkan Badan Peradilan Khusus yang dapat menangani sengketa Pilkada secara efektif. Mengingat objek dalam sengketa Pilkada terkait dengan problem administrasi pelaksanaan Pilkada, maka sebaiknya Badan Peradilan Khusus tersebut berada di bawah Peradilan Tata Usaha Negara. Pertimbangan lain adalah bahwa keberadaan PTUN secara geografis di setiap Provinsi dapat mendukung upaya penanganan sengketa Pilkada secara lebih efektif.

\section{REFERENSI}

Abdul Rasyid Thalib, (2006), Wewenang Mahkamah Konstitusi dan Implikasinya dalam sisitem Ketatanegaraan Republik Indonesia, Bandung: Citra Aditya Bakti.

Bisariyadi, Anna Triningsih, Meyrinda Rahmawaty H, Alia Harumdani W, (2012), Komparasi Mekanisme Penyelesaian Sengketa Pemilu di Beberapa Negara Penganut Paham Demokrasi Konstitusional, Jurnal Konstitusi, v9n3.

Djoko Suyanto, (2012), Evaluasi Pemilukada dari Prespektif Ketahanan Nasional: Demokrasi Lokal, Evaluasi Pemilukada di Indonesia, Jakarta: Konpress.

Jimly Asshiddiqie. (2002), Konsolidasi Naskah UUD 1945 Setelah Perubahan Keempat,

Depok: Pusat Studi Hukum Tata Negara Fakultas Hukum Universitas Indonesia.

Joko J. Prihatmoko, (2008), Mendemokrasikan Pemilu, Yogyakarta: Pustaka Pelajar.

Kariaman Sinaga, (2016), Efektitas Regulasi dan Perannya dalam Penyelenggaraan Pemilukada: Dialektika Hukum dan Etika Pemilukada Serentak, Jakarta: Dewan Kehormatan Penyelenggara Pemilu RI.

Mahkamah Konstitusi Republik Indonesia, (2010), Naskah Komprehensif Perubahan Undang-Undang Dasar Negara Republik Indonesia Tahun 1945, Buku IV: Kekuasaan Pemerintahan Negara Jilid 2, Edisi Revisi, Jakarta: Sekretariat Jenderal dan Kepaniteraan Mahkamah Konstitusi. 
Majelis Permusyawaratan Rakyat, (2000), Buku Kedua Jilid 3 C Risalah Rapat Panitia Ad Hoc I Sidang Tahunan 2000, Jakarta: Sekretariat Jenderal Majelis Permusyawaratan Rakyat.

Philipus M. Hadjon, et. al, (2008), Pengantar Hukum Adminstrasi Negara, Jogjakarta: UGM Pers.

R. Soeroso, (2001), Praktek Hukum Acara Perdata; Tata Cara dan Proses Persidangan, Jakarta: Sinar Grafika.

Ridwan H.R, (2006), Hukum Administrasi Negara, Jakarta: Raja Grafindo Persada.

Siti Nurhalimah, (2017), Pembentukan Badan Peradilan Khusus Pilkada, Buletin Hukum dan Keadilan 'Adalah, v1n5c.

www.mahkamahkonstitusi.go.id 